\title{
Determinations of phytochemical, vitamin, mineral and proximate compositions of varieties of watermelon seeds cultivated in Borno State, North - Eastern Nigeria
}

\author{
Gwana, A. M. ${ }^{1, ~}$, Bako, M. M. ${ }^{2}$, Bagudu, B. Y. ${ }^{3}$, Sadiq, A. B. ${ }^{4}$, Abdullahi, M. Mai ${ }^{5}$ \\ ${ }^{1}$ Laboratory Unit, Department of Animal Health and Production Technology, Mohamet Lawan, College of Agriculture, P.M.B. 1427, \\ Maiduguri, Nigeria \\ ${ }^{2}$ Department of Fisheries, Faculty of Agriculture, University of Maiduguri, P.M.B 1069, Maiduguri, Nigeria \\ ${ }^{3}$ Department of Science Laboratory Technology, Waziri Umaru Federal Polytechnic, Birnin Kebbi, Kebbi State, Nigeria \\ ${ }^{4}$ Department of Biochemistry, University of Maiduguri, P.M.B 1069, Maiduguri Nigeria \\ ${ }^{5}$ Department of Basic Science, Mohamet Lawan College of Agriculture, P.M.B. 1427, Maiduguri, Nigeria
}

\section{Email address:}

admuwana@yahoo.com (Gwana A. M.), mammadu09@gmail.com (Bako M. M.), hutawas@yahoo.co.uk (Bagudu B. Y.), a.aaji2k6@yahoo.com (Sadiq A. B.), mumin_abdullahi@yahoo.com (Abdullahi M. M.)

\section{To cite this article:}

Gwana, A. M., Bako, M. M., Bagudu, B. Y., Sadiq, A. B., Abdullahi, M. Mai. Determinations of Phytochemical, Vitamin, Mineral and Proximate Compositions of Varieties of Watermelon Seeds Cultivated in Borno State, North - Eastern Nigeria. International Journal of Nutrition and Food Sciences. Vol. 3, No. 4, 2014, pp. 238-245. doi: 10.11648/j.ijnfs.20140304.12

\begin{abstract}
This study on the determination of phytochemical, mineral, vitamins compositions and proximate analysis on watermelons seeds cultivated in Borno State, north - eastern Nigeria was conducted on the two varieties of Citrullus lanatus of Sassako and Rosmas. The fruits are selected directly from the farm randomly at Auno village, removed from the fruits, dried, processed under room temperature, subjected to analyses, as described by AOAC, (1990) and Ergan, Kirk and Sawyer, (1981). The findings revealed that, the fruits produced in this area are moderately large in size and weight. The Sassako fruit's, length, width, diameter and numbers of seeds content were more than that of the Rosmas variety, except the weight of the Rosmas seeds is slightly more than the Sassako seeds. The seeds contained six phytochemicals; alkaloids, anthraquinones, flavonoids, gallic acid, saponins, and tannins which are said to be an antioxidant, prevent and heals various diseases. The varieties of Sassako and Rosmas seeds possessed eight types of mineral elements in higher concentration levels $(\mathrm{mg} / \mathrm{kg}$ ). The Sassako variety (seeds) contains more concentration of potassium, copper, manganese, magnesium and calcium with less content of sodium, iron and zinc than when compared to Rosmas variety. Rosmas variety contains more quantities of minerals, includes; iron, zinc and sodium with less quantities of potassium, calcium, manganese, magnesium and copper when compared with the Sassako variety. The varieties of Rosmas and Sassako seeds contains six types of vitamins; $\mathrm{C}$, Total folate, $\mathrm{B}_{1}, \mathrm{~B}_{2}, \mathrm{~B}_{5}$ and $\mathrm{B}_{6}$ in a moderate concentration $(\mathrm{mg} / \mathrm{kg})$. The seeds of Rosmas variety contain more amounts of the vitamins than the Sassako variety; the seeds of Rosmas variety are the most preferable in terms of vitamin content. The result of the proximate analysis; Rosmas seed variety contained more moisture, crude fibres and crude fats than the Sassako variety, while Sassako seed variety had more ash, protein, carbohydrate and dry matter contents than the Rosmas variety. Statistical analysis of the variables were found to be highly significant, and accepted. The results support the works of most authors such as Ayoola et al, (2012); "Watermelon", (2008) and WHFoods, (2011). The findings revealed that, seeds of $C$. lanatus contained a very high concentration of nutrients for both human and livestock consumption, most preferable among the varieties is the Sassako, the fruits can grow very well in this area with a reasonable sizes, lot of matured black flatten and oval seeds. With large scale farming of the plant, lot of income would be generated.
\end{abstract}

Keywords: Citrulus Lanatus Varieties, Mineral, Phytochiemical, Proximate Analysis, Vitamin

\section{Introduction}

The crops of the Cucurbitaceae or Cucurbit are known as vine crops. These are member like, cucumber (Cucumis sativa), watermelon (Citrullus lanatus), muskmelon 
(Cucumis melo), pumpkin, squash and the chayote and are all warm season crops, very susceptible to cold injury [8, 10]. The vine crops are commonly called in Hausa language as "Tsirai Gorarroka" meaning gourd family plants. Watermelons originated in tropical Africa, and Sanskrit and early Egyptian records indicate that they have been cultivated for more than 4000 years [10]. Melons belong to the family Cucurbitaceae. Muskmelons, winter melons, and European cantaloupes grow on the vine classified as Cucumis melo. Muskmelons are derived from Cucumis melo variety reticulatus. Winter melons are derived from Cucumis melo variety inodorus. The true cantaloupe is classified as Cucumis melo variety cantalupensis. Watermelons grow on the vine classified as Citrullus lanatus [10]. Watermelon (Citrullus lanatus) is a type of melon, member of the gourd family, cultivated extensively for its pleasant-tasting fruit, is one of the most economically important fruit in the Cucurbitaceae family $[15,16]$. Watermelon grows as a trailing vine. Its original habitat was tropical Africa, particularly the region of the Kalahari Desert, but its popularity became widespread early in history, and today it is cultivated throughout the world [4, 15]. Watermelons grow on most United States vine acreages; native to Africa, they have achieved their greatest popularity in the United States, mostly in the Southern States, as far as North as Iowa. These ranges from 30lb fruits to small round "Ice box" typed weighing between 5 and $10 \mathrm{lb}$. There are also yellow - fleshed types, but the red is the most popular. The seedless Watermelon, a Triploid fruit first created in Japan in 1940's from crossing Tetraploid and Diploids has found its greatest success in Taiwan but still is just a novelty in the United States $[8,15$, 17]. The vine, an annual, is coarse and hairy and bears divided, oval leaves on short stalks and round, light yellow, individual flowers. The rounded, oblong, berrylike fruit grows to a very large size: Cultivated watermelons may reach $61 \mathrm{~cm}$ (24 in) in length and weigh $23 \mathrm{~kg}(50 \mathrm{lb})$. Their thick rinds are green or striped and the watery flesh is usually red in colour and contains many dark, flat seeds [15, 16]. Melons belong to the family Cucurbitaceae. Muskmelons, winter melons, and European cantaloupes grow on the vine classified as Cucumis melo. Muskmelons are derived from Cucumis melo variety reticulatus. Winter melons are derived from Cucumis melo variety inodorus. The true cantaloupe is classified as Cucumis melo variety cantalupensis. Watermelons grow on the vine classified as Citrullus lanatus [10]. Watermelon is also grown and became popular in the northern part of Nigeria, especially in the central and north - eastern Nigeria. There are more than 1200 varieties of watermelon ranges in size, shape and colour of the flesh, shipping ability of rind and sweetness of the flesh. The name Watermelon is generally acceptable, but, the name of different varieties may be given due to the colour, shape, level of sweetness or location or place of the first cultivation of the variety. Hence, the name given to a variety may not be acceptable in another place, $[3,2,16]$. Watermelon is used amazingly for it nutritional and medicinal values because of its high water content which contained sugar and energy booster, which hydrate body in the case of dehydration, especially during the hot seasons $[2,6]$. Watermelon's Seeds, the dried seeds (dark flat) of the fruit are used as snacks when salted and roasted in China, Israel, etc. In Africa, the seeds are made into coarse flour or oil may be extracted from them and use for domestic consumption, and the juice can be extracted from watermelon to produced wine. The imperfect fruit of the Watermelon are used as Livestock feed, while the immature fruits may be prepared and used as summer squash [4]. Watermelon was said to possessed high level of antioxidants (Phytochemical property) which decreases the risk of kidney stone and bone lose due to old age, and it is a powerful diuretic diet, has the availability of amino acids and Beta - Carotene which protect heart disease. Also rich in lycopene, which is a pigment that gives the red colour that naturally, occurred in Citrulus lanatus which prevent ailments of prostate and oral cancer. It is a good source of vitamins such as A, B, C, and Thiamine. The seeds of the watermelon are said to contained considerable amount of minerals such as calcium, iron, manganese, phosphorus, potassium, sodium, zinc, copper and magnesium which assist in the growth and development of the healthy body which take part in metabolic activities of all living organisms $[3,12,13,15,16,18]$. The objectives of this research study are to screen and evaluate the Phytochemical, proximate analysis, mineral and vitamins composition of Watermelon's Seeds that has been cultivated in Borno, North - Eastern Nigeria.

\section{Methodology}

\subsection{Study Area and Location}

The study was conducted in Maiduguri, Borno state. The state is located in the North - Eastern region of Nigeria, and is among the six geo - political zones of the Federal Republic Nigeria. Borno State shares local boundaries with Adamawa, Gombe and Yobe States and international boundaries with Cameroon, Chad and Niger Republics. It has a few establishment, businessmen and women, but the majority of the local people are small scale business community, farmers, fishermen and herdsmen, Islamic and Western scholars. The local farmers usually sow plant crops such as Millet, Sorghum, Cowpea, Groundnuts, Maize, Fruits Crops such as Watermelons, Cucumber, etc, and some vegetables. They also reared livestock such as Cattle, Camel, Sheep, Goat and both local and exotic poultry farming are being practiced. The major languages used in communication are Kanuri, Shuwa-Arab, Babur-bura, Marghi language, Fulfulde, Chibok, Hausa and English respectively. In addition, the capital city serve as a centre of education, business, and health facilities are given at primary, secondary, and tertiary levels of health care Institutions, (Gwana, 2005). Borno State has an area landmark of about 70,898 square kilometres $\left(70898 \mathrm{~km}^{2}\right)$, 
which was located between latitude $11^{0} 30^{\prime \prime}$ North to $13^{0} 00^{\prime \prime}$ North and longitude $11.5^{\circ} 00^{\prime \prime}$ East respectively. It has an estimated population of about 4,151,193 people, out of which 2,163,358 are males and 2,007,746 are females, and the population density is 37 persons per kilometre squares $\left(37 / \mathrm{km}^{2}\right)$, (NPC, 2006). The climatic condition in this area is of a hot dry season $\left(27^{\circ} \mathrm{c}\right.$ to $\left.42^{\circ} \mathrm{c}\right)$, generally and the annual rainfall of 500 to $600 \mathrm{~mm}$ has been recorded [7].

\subsection{Materials Use}

The following standard materials were required and used in the cause of this scientific research study and Standard Operation Procedures (SOP) are absolutely been observed.

\subsubsection{Apparatus Used}

Plastic tray, bucket, bowl, cutting knife, plastic spatula, clean white cotton cloth, sterile absorbable cotton wool, plastic sieve, crucible dish, reagent bottles (various types), measuring cylinder, flasks $(50 \mathrm{ml}, 100 \mathrm{ml}, 250 \mathrm{ml}, 500 \mathrm{ml}$, and $1000 \mathrm{ml}$ ), large mouth, brown, sample bottles, Whatman filter paper (No.1), hand gloves, hot air oven, muffle furnace, Vanier calliper, measuring tape, weighing balance, analytical balance, atomic absorption spectrophotometer (AAS) and flame photometer.

\subsubsection{Reagents Used}

Tap water, distilled water, deionised water, hydrogen hypochlorite solution (bleach solution), hydrochloric acid ( $\mathrm{HCl}$ of known molarity and concentration), potassium hydroxide ( $\mathrm{KOH}$ of known molarity and concentration), Kheldahl reagents and AOAC standard reagents.

\subsection{Method Used}

The following methods were applied and used in the cause of this study and standard operation procedures (SOP) are absolutely been observed.

\subsubsection{Sample Collection}

Samples of two (2) varieties of Watermelon's (C. lanatus) fruits commonly called in Borno as "Kankanan rosmas" and "Kankanan sassako" were randomly selected and collected directly from the farm were they had been cultivated at Auno town, Borno State, in the morning time, and various sizes and shape were obtained. The samples were then transported to the Laboratory, College of Agriculture, Maiduguri, for the processing and analysis of the fruit's Seeds.

\subsubsection{Watermelon's Seeds Processing}

The Laboratory bench was washed, cleaned and disinfected with hydrogen hypochlorite (bleach) solution soaked with cotton wool. The Watermelon's fruits were washed in tap water, rinse in distilled water, and lastly in deionised water and were allowed to drained respectively. The weight and the length of the watermelon's fruits were taken by using measuring tape and weighing balance. The watermelon's fruits were cut into two (2) at the centre and the diameter were read and taken. It was then cut again radially in to long slices and the Seeds (a black, dark greyish flattened Seeds) were removed from the sliced fruit by using plastic Spatula and transferred into plastic bucket contained tap water. It was washed thoroughly with tap water and sieved through a plastic Sieve. It was then rinsed with distilled water and lastly with deionised water and drained respectively. The Seeds were air dried at room temperature and later dried in an Oven at $105^{\circ} \mathrm{C}$ over night. The Seeds' weight, length and diameter were measured and taken by using Vanier calliper and analytical balance. Lastly, some amount of the Seeds were packed, reserved and shelved for feature used and reference, while, some amount were ash at $550^{\circ} \mathrm{C}$ by using Muffle furnace, and the greyish - whitish ash were packed in to a large mouth brown bottles ready to be used.

\subsubsection{Methods Applied}

The methods applied in the evaluation of the functional chemicals (Phytochemicals) were determined from the Watermelon's seeds of the two (2) varieties with the accordance to the methods described by Mittal et al, (1981), Fernando et al; (1989) and AOAC, (1990),. The moisture content was determined by drying the seeds sample at $105^{\circ} \mathrm{C}$ in an Oven, ash content by ignition at $550^{\circ} \mathrm{C}$ in a Muffle furnace for six (6) hours, oil content extraction was done by Soxhlet extraction techniques with methyl - ether, Protein content by the Kheldahl techniques (using digesting catalyst - Kheldahl tablets), and crude fibre content estimation was done by the acid - alkaline digestion methods as described by Less, (1975) and AOAC, (1990). The Carbohydrate content was estimated by the difference, subtracting from the sum of water, protein, fat, crude fibre and ash percentages from one hundred (100) as described by Ayoola el al, (2012). Vitamins (Ascorbic acid content and compositions of water soluble vitamins such as riboflavin and thiamine) and Minerals of each sample of the dried and ashed watermelon's seeds were determined by digesting the ash with $3 \mathrm{M}$ Hydrochloric acid $(\mathrm{HCl})$, while the atomic absorption spectrophotometer (AAS) was used to determined calcium, magnesium, manganese, and iron. Potassium and sodium were determined by Flame photometer, as described by Ergan, Kirk and Sawyer, (1981), and AOAC, (1990).

\subsection{Data Analysis Applied}

Data obtained were subjected to simple statistical tools of analysis by using Mean, Standard Deviation and percentage in order to ascertain the significance of the variables obtained, as described by Stroud \& Booth, (2001).

\section{Results}

The results obtained from the Phytochemicals, proximate compositions, vitamin and mineral evaluation on the two varieties of watermelons seeds (Citrullus lanatus seeds of Rosmas and Sassako varieties) that were cultivated in Borno, Nigeria showed the following information bellow: 
3.1. Table 1 showed the measurements taken on the Rosmas variety of water melon fruits, mean weight of the smallest fruit was $0.97 \mathrm{~kg}$, the medium $(2.4 \mathrm{~kg})$ and the largest $(5.8 \mathrm{~kg})$. mean length of the smallest fruit was 18.8 $\mathrm{cm}$, medium $(23.1 \mathrm{~cm})$ and the largest $(32.5 \mathrm{~cm})$. The mean width of the smallest fruit was $8.6 \mathrm{~cm}$; medium $(12.1 \mathrm{~cm})$ and the largest $(16.2 \mathrm{~cm})$.

3.2. Table 2 showed the measurements made on the Sassako variety of water melons fruit (Citrullus lanatus), the mean weight of the smallest fruit was $0.95 \mathrm{~kg}$, the medium $(2.2 \mathrm{~kg})$ and the largest $(5.43 \mathrm{~kg})$. The mean length measurement of the smallest fruit was $(13.8 \mathrm{~cm})$, medium $(17.83 \mathrm{~cm})$ and the largest $(25.0 \mathrm{~cm})$. The mean width of the smallest fruit was $(6.87 \mathrm{~cm})$, medium $(101 \mathrm{~cm})$ and the largest $(15.03 \mathrm{~cm})$.

3.3. Table 3 showed the measurement taken on the seeds of the Rosmas variety of $C$. lanatus fruits; the mean numbers of seeds of the smallest (187), medium (363) and largest (622) of Rosmas variety. The mean weight values of the smallest fruit seeds is $(0.047 \mathrm{mg})$, medium $(0.047 \mathrm{mg})$ and largest $(0.047 \mathrm{mg})$. The mean length of the smallest fruit $\mathrm{s}$ seeds is $(1.4 \mathrm{~mm})$, medium $(1.6 \mathrm{~mm})$ and the largest $(1.8 \mathrm{~mm})$, while the diameter of smallest, medium and the largest fruit seeds were $1.0 \mathrm{~mm}, 1.2$ and $1.4 \mathrm{~mm}$.

3.4. Table 4 showed the measurements taken on the Sassako variety of water melon ( $C$. lanatus) seeds; the mean numbers of seeds found to contain in the smallest is 191, medium (400) and the largest fruits (672). The mean weights of the seeds obtained from the smallest fruits 0.053 $\mathrm{mg}$, medium $(0.053 \mathrm{mg})$ and largest $(0.053 \mathrm{mg})$. The mean lengths of the seeds of the smallest fruit seed is $0.8 \mathrm{~mm}$, medium $(1.2 \mathrm{~mm})$ and the largest $(1.4 \mathrm{~mm})$.while the mean diameter taken from the seeds of the smallest, medium and largest fruits were $1.1 \mathrm{~mm}, 1.5 \mathrm{~mm} 1.8 \mathrm{~mm}$.

3.5. Table 5 showed the Phytochemicals composition evaluated in percentage from the analysis carried out on the water melon seed of the Rosmas variety. The seed was found to possess six types of phytochemicals which includes; saponins $(0.088 \%$, ), alkaloids $(0.086 \%$, ), tannins $(0.026 \%)$, anthraquinones $(0.014 \%$, ), flavonoids $(0.005 \%)$ and gallic $(0.003 \%)$.
3.6. Table 6 showed the percentage of the phytochemicals composition of the analysis conducted on the Sassako variety of water melon seeds. The seeds of this variety of $C$. lanatus were found to contain six types of phytochemicals also, which comprises of alkaloids $(0.91 \%$, ), saponins $(0.09 \%$, ), tannins $(0.04 \%$, anthraquinones $(0.012 \%)$, flavonoids $(0.01 \%)$ and gallic $(0.01 \%)$.

3.7. Table 7 showed the percentages for the proximate compositions analysis made on the seeds of the Rosmas variety of the C. lanatus seeds (moisture 10.8\%, ash 5.01\%, crude fibre $8.0 \%$, crude fat $2.8 \%$, protein $5.8 \%$, carbohydrate $67.6 \%$ and the dry matter $89.2 \%$ ).

3.8. Table 8 showed analysis the proximate compositions percentages on the seeds of the Sassako variety of the $C$. lanatus seeds which includes; moisture, ash, crude fibre, crude fat, protein, carbohydrate and dry matter contents which are $10.5 \%, 5.1 \%, 7.8 \%, 2.6 \%, 6.1 \%, 67.8 \%$ and $89.5 \%$.

3.9. Table 9 showed the types of vitamins and their concentration contained in the seeds of Rosmas variety of watermelon. The seeds were found to contain six different vitamins and their quantities, which are; $\mathrm{B}_{1}(0.22 \mathrm{mg}), \mathrm{B}_{2}$ (0.07 mg), $\mathrm{B}_{5}(0.35 \mathrm{mg}), \mathrm{B}_{6}(0.47 \mathrm{mg}), \mathrm{C}(1.09)$ and Total Folate $(0.18 \mathrm{mg})$.

3.10. Table 10 showed the types and the concentration of vitamins contain in the seeds of Sassako variety of $C$. lanatus. The available vitamins found were; $B_{1}(0.16 \mathrm{mg})$, $\mathrm{B}_{2}(0.05 \mathrm{mg}), \mathrm{B}_{5}(0.27 \mathrm{mg}), \mathrm{B}_{6}(0.45 \mathrm{mg}), \mathrm{C}(0.91 \mathrm{mg})$ and Total Folate $(0.11 \mathrm{mg})$.

3.11. Table 11 showed the Minerals concentration of Rosmas variety seeds (C. lanatus) in $\mathrm{mg} / \mathrm{kg}$; Potassium (3187.0 mg), Sodium (2520.87 mg), Magnesium (1511.05 $\mathrm{mg}$ ), Calcium (1472.80 mg), Iron (1202.05 mg), Zinc (37.03 mg), Manganese (22.90 mg) and Copper (15.02 mg).

3.12. Table 12 showed the Minerals concentration analysed from Sassako variety seeds (C. lanatus), evaluated in $\mathrm{mg} / \mathrm{kg}$; Potassium (3252.10 mg), Sodium (2519.1 mg), Calcium (2076.07 mg), Magnesium (1608.67 mg), Iron (90.65 mg), Zinc (35.0 mg), Manganese (23.50 mg), and Copper (16.57 mg).

Table 1. Showed the Measurement Values of Rosmas Variety (Watermelon) Fruit's Weight, Length and Width.

\begin{tabular}{|c|c|c|c|c|c|c|c|c|c|c|}
\hline \multirow{2}{*}{$\begin{array}{l}\text { Variety of C. } \\
\text { lanatus }\end{array}$} & \multirow{2}{*}{$\begin{array}{l}\text { Measurement } \\
\text { Trials }\end{array}$} & \multicolumn{3}{|c|}{ Weight in Kilograms } & \multicolumn{3}{|c|}{ Length in Centimetres } & \multicolumn{3}{|c|}{ Width in Centimetres } \\
\hline & & Small & Medium & Large & Small & Medium & Large & Small & Medium & Large \\
\hline \multirow[t]{6}{*}{ Rosmas } & First & 0.96 & 2.4 & 5.9 & 18.7 & 23.2 & 32.5 & 8.6 & 12.1 & 16.3 \\
\hline & Second & 1.00 & 2.4 & 5.7 & 18.6 & 22.8 & 32.4 & 8.6 & 12.0 & 16.2 \\
\hline & Third & 1.10 & 2.4 & 5.8 & 19.0 & 23.2 & 32.5 & 8.6 & 12.1 & 16.2 \\
\hline & Total & 2.96 & 7.2 & 17.4 & 56.3 & 69.2 & 97.4 & 25.8 & 36.2 & 48.7 \\
\hline & Mean & 0.97 & 2.4 & 5.8 & 18.8 & 23.1 & 32.5 & 8.6 & 12.1 & 16.2 \\
\hline & $\pm \mathrm{STDEV}$ & \pm 0.07 & \pm 0.0 & \pm 0.1 & \pm 0.21 & \pm 0.23 & \pm 0.06 & \pm 0.0 & \pm 0.06 & \pm 0.06 \\
\hline
\end{tabular}


Table 2. Showed the Measurement Values of Sassako Variety (Watermelon) Fruit's Weight, Length and Width.

\begin{tabular}{|c|c|c|c|c|c|c|c|c|c|c|}
\hline \multirow{2}{*}{$\begin{array}{l}\text { Variety of } \\
\text { C. lanatus }\end{array}$} & \multirow{2}{*}{$\begin{array}{l}\text { Measurement } \\
\text { Trials }\end{array}$} & \multicolumn{3}{|c|}{ Weight in Kilograms } & \multicolumn{3}{|c|}{ Length in Centimetres } & \multicolumn{3}{|c|}{ Width in Centimetres } \\
\hline & & Small & Medium & Large & Small & Medium & Large & Small & Medium & Large \\
\hline \multirow{6}{*}{ Sassako } & First & 0.90 & 2.2 & 5.5 & 13.9 & 18.0 & 25.0 & 7.0 & 10.1 & 15.1 \\
\hline & Second & 1.00 & 2.5 & 5.4 & 13.7 & 17.9 & 25.0 & 6.6 & 10.2 & 15.0 \\
\hline & Third & 0.95 & 2.1 & 5.4 & 13.8 & 17.8 & 25.0 & 6.8 & 10.0 & 15.0 \\
\hline & Total & 2.85 & 6.6 & 16.3 & 41.4 & 53.5 & 75.0 & 20.6 & 30.3 & 45.1 \\
\hline & Mean & 0.95 & 2.2 & 5.43 & 13.8 & 17.86 & 25.0 & 6.87 & 10.1 & 15.03 \\
\hline & $\pm \mathrm{STDEV}$ & \pm 0.05 & \pm 0.1 & \pm 0.06 & \pm 0.1 & \pm 0.15 & \pm 0.12 & \pm 0.12 & \pm 0.1 & \pm 0.06 \\
\hline
\end{tabular}

Table 3. Showed the Measurement Values of Rosmas Variety (Watermelon) Seed Quantity, Weight, Length and Width.

\begin{tabular}{|c|c|c|c|c|c|c|c|c|c|c|c|c|c|}
\hline \multirow{2}{*}{$\begin{array}{l}\text { Variety } \\
\text { Of } C . \\
\text { lanatus. }\end{array}$} & \multirow{2}{*}{$\begin{array}{l}\text { Measurement } \\
\text { Trials. }\end{array}$} & \multicolumn{3}{|c|}{ Quantity of Seed per variety } & \multicolumn{3}{|c|}{ Weight of Seed in mg } & \multicolumn{3}{|c|}{ Length of Seed in mm } & \multicolumn{3}{|c|}{ Diameter of Seed in $\mathbf{~ m m}$} \\
\hline & & Small & Medium & Large & Small & Medium & Large & Small & Medium & Large & Small & Medium & Large \\
\hline \multirow{6}{*}{ Rosmas } & First. & 187 & 363 & 621 & 0.04 & 0.05 & 0.03 & 1.3 & 1.6 & 1.9 & 1.0 & 1.2 & 1.4 \\
\hline & Second. & 186 & 363 & 623 & 0.05 & 0.06 & 0.05 & 1.4 & 1.5 & 1.8 & 1.0 & 1.2 & 1.5 \\
\hline & Third. & 187 & 363 & 621 & 0.06 & 0.05 & 0.06 & 1.3 & 1.6 & 1.8 & 1.0 & 1.1 & 1.4 \\
\hline & Total. & 560 & 1,089 & 1,865 & 0.14 & 0.14 & 0.14 & 4.2 & 4.7 & 5.5 & 3.0 & 3.5 & 4.3 \\
\hline & Mean. & 186.7 & 363 & 621.7 & 0.047 & 0.047 & 0.047 & 1.4 & 1.6 & 1.8 & 1.0 & 1.2 & 1.4 \\
\hline & \pm STDEV. & \pm 0.58 & \pm 0.0 & \pm 1.15 & \pm 0.015 & \pm 0.006 & \pm 0.015 & \pm 0.06 & \pm 0.06 & \pm 0.06 & \pm 0.0 & \pm 0.06 & \pm 0.06 \\
\hline
\end{tabular}

Table 4. Showed the Measurement Values of Sassako Variety (Watermelon) Seed Quantity, Weight, Length and Width.

\begin{tabular}{|c|c|c|c|c|c|c|c|c|c|c|c|c|c|}
\hline \multirow{2}{*}{$\begin{array}{l}\text { Variety } \\
\text { Of } C . \\
\text { lanatus. }\end{array}$} & \multirow{2}{*}{$\begin{array}{l}\text { Measurement } \\
\text { Trials. }\end{array}$} & \multicolumn{3}{|c|}{ Quantity of Seed per variety. } & \multicolumn{3}{|c|}{ Weight of Seed in mg } & \multicolumn{3}{|c|}{ Length of Seed in $\mathrm{mm}$} & \multicolumn{3}{|c|}{ Diameter of Seed in $\mathrm{mm}$} \\
\hline & & Small & Medium & Large & Small & Medium & Large & Small & Medium & Large & Small & Medium & Large \\
\hline \multirow{6}{*}{ Sassako } & First. & 191 & 399 & 672 & 0.04 & 0.04 & 0.05 & 0.7 & 1.2 & 1.4 & 1.3 & 1.4 & 1.8 \\
\hline & Second. & 192 & 401 & 672 & 0.05 & 0.07 & 0.06 & 0.8 & 1.2 & 1.5 & 1.1 & 1.5 & 1.8 \\
\hline & Third. & 191 & 400 & 67. & 0.07 & 0.05 & 0.05 & 0.8 & 1.4 & 1.4 & 1.2 & 1.5 & 1.8 \\
\hline & Total. & 574 & 1270 & 2017 & 0.16 & 0.16 & 0.16 & 2.3 & 3.55 & 4.3 & 3.6 & 4.4 & 5.4 \\
\hline & Mean. & 191.3 & 400 & 672.3 & 0.053 & 0.053 & 0.053 & 0.8 & 1.2 & 1.4 & 1.1 & 1.5 & 1.8 \\
\hline & \pm STDEV & \pm 0.58 & \pm 0.0 & \pm 1.15 & \pm 0.015 & \pm 0.015 & \pm 0.015 & \pm 0.06 & \pm 0.06 & \pm 0.06 & \pm 0.1 & \pm 0.06 & \pm 0.0 \\
\hline
\end{tabular}

Table 5. Showed the Phytochemical Concentration of Rosmas variety Seed (Water Melon) in percentage.

\begin{tabular}{llllll}
\hline Trials & Alkaloid & Anthraquinones & Flavonoid & Gallic acid & Saponins \\
\hline First reading & 0.87 & 0.015 & 0.006 & 0.003 & 0.088 \\
Second reading & 0.85 & 0.013 & 0.004 & 0.002 & 0.027 \\
Third reading & 0.86 & 0.013 & 0.005 & 0.003 & 0.025 \\
Total (Mean \pm & & $0.041(0.014 \pm$ & $0.015(0.005 \pm$ & $0.008(0.003 \pm$ & $0.265(0.088 \pm$ \\
STDev) & $2.58(0.86 \pm 0.01)$ & $0.001)$ & $0.001)$ & $0.001)$ & $0.075(0.026 \pm$ \\
\hline
\end{tabular}

Table 6. Phytochemical Concentration of Sassako variety Seed, (Water Melon) in percentage.

\begin{tabular}{lllllll}
\hline Trials & Alkaloid & Anthraquinones & Flavonoids & Gallic acid & Saponins & Tannins \\
\hline First reading & 0.92 & 0.012 & 0.005 & 0.006 & 0.095 & 0.035 \\
Second reading & 0.90 & 0.011 & 0.004 & 0.006 & 0.095 & 0.034 \\
Third reading & 0.91 & 0.012 & 0.005 & 0.005 & 0.094 & 0.035 \\
Total (Mean \pm & $2.73(0.91 \pm 0.01)$ & $0.35(0.012 \pm$ & $0.014(0.01 \pm$ & $0.017(0.01 \pm$ & $0.284(0.09 \pm$ & $0.104(0.04 \pm$ \\
STDev) & $0.001)$ & $0.001)$ & $0.001)$ & $0.001)$ & $0.001)$. \\
\hline
\end{tabular}

Table 7. Proximate Composition and concentration level of Rosmas variety Seed (Watermelon) in percentage.

\begin{tabular}{llllllll}
\hline Trials & Moisture & Ash & Crude Fibre & Crude Fat & Protein & Carbohydrate & Dry Matter \\
\hline Concentration in percentage & & & & & & \\
First reading & 10.7 & 5.1 & 8.0 & 2.8 & 5.8 & 67.6 & 89.3 \\
Second reading & 10.8 & 5.1 & 7.9 & 2.8 & 5.9 & 67.5 & 89.2 \\
Third reading & 10.8 & 5.0 & 8.0 & 2.8 & 5.8 & 67.6 & 89.2 \\
Total (mean \pm & $32.3(10.8 \pm$ & $15.2(5.01 \pm$ & $23.9(8.0 \pm$ & $8.4(2.8 \pm 0.06)$ & $17.5(5.8 \pm$ & $202.7(67.6 \pm$ & $267.7(89.2 \pm$ \\
STDev.) & $0.06)$ & $0.06)$ & $0.06)$ & & & & \\
\hline
\end{tabular}


Table 8. Showed the Proximate analysis of Sassako Variety Seed (Water Melon) in Percentage.

\begin{tabular}{llllllll}
\hline Trials & Moisture & Ash & Crude Fibre & Crude Fat & Protein & Carbohydrate & Dry Matter \\
\hline \multicolumn{2}{l}{ Concentration in percentage } & & & & & & \\
First reading & 10.5 & 5.1 & 7.8 & 2.6 & 6.1 & 67.9 & 89.5 \\
Second reading & 10.6 & 5.1 & 7.9 & 2.7 & 6.0 & 67.7 & 89.4 \\
Third reading & 10.5 & 5.2 & 7.8 & 2.6 & 6.1 & 67.8 & 89.5 \\
Total (mean \pm & $31.6(10.5 \pm$ & $15.4(5.1 \pm$ & $23.5(7.8 \pm$ & $7.9(2.6 \pm 0.06)$ & $18.2(6.1 \pm$ & $203.4(67.8 \pm$ & $268.4(89.5 \pm$ \\
STDev.) & $0.06)$ & $0.06)$ & $0.06)$ & & & & $0.10)$ \\
\hline
\end{tabular}

Table 9. Vitamin concentration of Rosmas Variety Seed( Watermelon) in $\mathrm{mg} / \mathrm{kg}$.

\begin{tabular}{lllllll}
\hline Trials & \multicolumn{1}{c}{$\mathbf{B}_{\mathbf{1}}$} & $\mathbf{B}_{\mathbf{2}}$ & $\mathbf{B}_{\mathbf{5}}$ & $\mathbf{B}_{\mathbf{6}}$ & $\mathbf{C}$ & Total Folate \\
\hline Concentration in $\mathrm{mg} / \mathrm{kg}$ & & & & & & \\
First reading & 0.22 & 0.09 & 0.36 & 0.49 & 1.1 & 0.18 \\
Second reading & 0.22 & 0.06 & 0.35 & 0.47 & 1.2 & 0.17 \\
Third reading & 0.21 & 0.07 & 0.35 & 0.46 & 0.98 & 0.18 \\
Total (Mean \pm STDev) & $0.65(0.22 \pm 0.01)$ & $0.22(0.07 \pm 0.02)$ & $1.06(0.35 \pm 0.01)$ & $1.42(0.47 \pm 0.015)$ & $1.28(1.09 \pm 0.11)$ & $0.53(0.18 \pm 0.01)$ \\
\hline
\end{tabular}

Table 10. Vitamin Concentration of Sassako Variety Seed (Watermelon) in $\mathrm{mg} / \mathrm{kg}$.

\begin{tabular}{lllllll}
\hline Trials & $\mathbf{B}_{\mathbf{1}}$ & $\mathbf{B}_{\mathbf{2}}$ & $\mathbf{B}_{\mathbf{5}}$ & $\mathbf{B}_{\mathbf{6}}$ & $\mathbf{C}$ & Total Folate \\
Concentration in $\mathrm{mg} / \mathrm{kg}$ & & & & & \\
First reading & 0.17 & 0.05 & 0.28 & 0.44 & 0.90 & 0.12 \\
Second reading & 0.16 & 0.05 & 0.26 & 0.45 & 0.92 & 0.10 \\
Third reading & 0.16 & 0.04 & 0.27 & 0.45 & 0.91 & 0.11 \\
Total (Mean \pm & $0.49(0.16 \pm 0.01)$ & $0.14(0.05 \pm 0.01)$ & $0.81(0.27 \pm 0.01)$ & $1.34(0.45 \pm 0.01)$ & $2.73(0.91 \pm 0.01)$ & $0.33(0.11 \pm 0.01)$ \\
STDev) & & & & &
\end{tabular}

Table 11. Showed the Mineral Concentration of Rosmas Variety Seed (Watermelon) in mg / kg.

\begin{tabular}{lccllllll}
\hline Trials & Calcium & Magnesium & Manganese & Cupper & Zinc & Iron & Sodium & Potassium \\
\hline Concentration in & mg per kg & & & & & & & \\
First reading & 1473.00 & 1511.27 & 23.1 & 15.14 & 37.3 & 1202.00 & 2521.00 & 3187.00 \\
Second reading & 1472.79 & 1511.22 & 22.8 & 14.81 & 37.0 & 1201.96 & 2520.56 & 3286.96 \\
Third reading & 1472.61 & 1510.97 & 22.9 & 15.10 & 36.8 & 1202.20 & 2521.10 & 3187.00 \\
Total & 4418.40 & 4533.46 & 68.8 & 45.05 & 111.1 & 3606.16 & 7562.66 & 9560.96 \\
Mean & 1472.8 & 1511.15 & 22.9 & 15.02 & 37.03 & 1202.05 & 2520.87 & 3187.00 \\
\pm STDev & \pm 0.20 & \pm 0.16 & \pm 0.15 & \pm 0.18 & \pm 0.25 & \pm 0.13 & \pm 0.29 & \pm 0.02 \\
\hline
\end{tabular}

Table 12. Showed the Mineral Concentration of Sassako Variety Seed (Watermelon) in $\mathrm{mg} / \mathrm{kg}$.

\begin{tabular}{lllllllll}
\hline Trials & Calcium & Magnesium & Manganese & Cupper & Zinc & Iron & Sodium & Potassium \\
\hline Concentration in mg per kg & & & & & & & & \\
First reading & 2076.0 & 1608.69 & 23.4 & 16.58 & 35.3 & 91.0 & 2519.0 & 3252.0 \\
Second reading & 2076.1 & 1608.67 & 23.6 & 16.56 & 34.5 & 90.96 & 2519.2 & 3252.2 \\
Third reading & 2076.1 & 1608.66 & 23.5 & 16.56 & 35.2 & 90.98 & 2519.1 & 3252.1 \\
Total & 6228.20 & 4826.02 & 70.5 & 49.70 & 105.0 & 271.94 & 7557.3 & 9756.30 \\
Mean & 2076.07 & 1608.67 & 23.5 & 16.57 & 35.33 & 90.98 & 2519.1 & 3252.1 \\
\pm STDev & \pm 0.058 & \pm 0.015 & \pm 0.10 & \pm 0.012 & \pm 0.153 & \pm 0.020 & \pm 0.10 & \pm 0.10 \\
\hline
\end{tabular}

\section{Discussion}

Plant and its parts essential oils and extracts have been in use for many years, for their nutritional and medicinal values; for such as food preservation, pharmaceuticals, alternative medicine and natural therapies. Therefore, it became necessary to screen, investigate and evaluate these plants scientifically, which have been used in treating ailments traditionally, and as food and spice nutritionally. Watermelon (Citrulus lanatus) varieties would not be left out for their nutritional and medicinal values, especially the Rosmas and Sassako varieties in these senses.

The varieties of watermelon fruits cultivated in this studied area, are that of Sassako and Rosmas varieties of $C$. lanatus of which the largest fruits were mean weighed 5.8 $\mathrm{kg}$ and $5.4 \mathrm{~kg}$, while their mean length were $32.5 \mathrm{~cm}$ and $25.0 \mathrm{~cm}$ and lastly their mean width were $16.2 \mathrm{~cm}$ and 15.0 $\mathrm{cm}$. The mean numbers of seeds content of each fruit were 672 in Sassako fruit and 622 in Rosmas fruit. The mean diameters of seeds were $1.8 \mathrm{~mm}$ for Sassako and $1.4 \mathrm{~mm}$ for Rosmas, while the mean weight of the seed each are $0.047 \mathrm{mg}$ and $0.053 \mathrm{mg}$ been recorded. From the results of the analyses conducted, it was found that Sassako variety in terms of fruit's weight, length, width, numbers of seeds content and the diameter of the seeds were more than that of the Rosmas variety of the water melon seeds. But the 
weight of the Rosmas variety seeds is slightly more than the Sassako seeds variety of water melon.

Both the Rosmas and the Sassako varieties of C. lanatus seeds contain six types of phytochemicals which were same, except that, the percentage of quantities varies with one another. In Rosmas variety, the highest in percentage among the six phytochemicals evaluated is saponins, while the least is gallic acid. Hence, in Sassako variety, alkaloid has the highest quantity, while flavonoids and the gallic acid have the lowest quantities.

The results revealed that, Rosmas variety contained more moisture, crude fibres and crude fats than the Sassako variety. While Sassako variety of the C. lanatus seeds had more ash, protein, carbohydrate and dry matter contents than that of the Rosmas variety seeds.

The results also revealed that, both the seeds of the Rosmas and Sassako varieties of Citrullus lanatus contain six types of Vitamins, these were; Vitamin C, Vitamin B complex ( $\mathrm{B}_{1}, \mathrm{~B}_{2}, \mathrm{~B}_{5}$ and $\mathrm{B}_{6}$ only) and the total folate in a moderate quantities. It was found that, the seeds of Rosmas variety contain more quantities of the six vitamins present than the seeds of the Sassako variety. Thus, in terms of vitamins contents, Rosmas variety is the most preferable.

In another findings from the results obtained, it revealed that both the varieties of the Sassako and that of the Rosmas seeds possessed eight (8) types of mineral elements in higher quantities (milligrams per kilogram) of the seeds. The Sassako variety (seeds) contains more quantities of potassium, copper, manganese, magnesium and calcium with less content of sodium, iron and zinc, when compared to Rosmas variety of water melon seeds. Finally, Rosmas variety contains more quantities of minerals which includes; iron, zinc and sodium with less quantities of potassium, calcium, manganese, magnesium and copper, and when compared to that of the Sassako variety of the Citrullus lanatus seeds. Statistically, variable were found to be highly significant and the results are accepted. The results obtained support the works most authors such as that of, "Watermelon", (2008); Health Benefit, (2011); WHFoods, (2011); Ayoola et al, (2012).

\section{Conclusion}

The determinations and evaluation of phytochemical, proximate composition, vitamins and mineral from the two varieties of the Water melons (C. lanatus) seeds; the Sassako and Rosmas varieties which were cultivated in Borno, north - eastern Nigeria was conducted in Maiduguri the state capital of Borno state, Nigeria. The results obtained are presented in percentages and milligrams, while measurements and weighing of the fruits and that of the seeds and number of seeds contained in fruit, and sizes of watermelon varieties (C. lanatus), are reported in centimetres, millimetres, Kilograms and milligrams respectively. These varieties of $C$.lanatus seeds were found to contained six phytochemicals, proximate compositions were known, vitamins and mineral in moderate, considerable and significant concentrations.

With these findings, the seeds of the fruits of the plant $(C$. lanatus) are very good and contained a very high concentration of nutrients for both human and livestock consumption, also possessed medicinal values as a plant products and the most preferable among the varieties of the water melon is the Sassako variety of which, the fruits can grow very well in this studied area, with a reasonable sizes up to great and large in sizes with a lot of matured black flatten and oval seeds.

\section{Recommendations}

When these plant varieties fruits (C. Lanatus) were been cultivated in large scale farming (Horticultural farming), a lots of products would be obtained from the foods and oil mill industries that processing them and a lot of income would be generated which will increase the Gross Domestic Products and Income at large. The Government and Private sectors are urged to encourage the large scale farmers to participate in the cultivation of watermelon of the varieties of Sassako and Rosmas, this is because of its economic values which would increase the Gross. Domestic Income of the nation at large. Local farmers and the Partisan farmers are to be encouraged and enlightened on the modern techniques of the cultivation and production of watermelon fruits and its seeds due to its nutritional and medicinal values by the Horticulture Extension Workers.

\section{References}

[1] AOAC, Official Methods of Analysis, In: Association of Official Analytical Chemists, AOAC Press; Gaithersburg, Washington D.C, USA. $15^{\text {th }}$ Edition; Pp. 71 -92. 1990.

[2] Ayoola, P.B; Adeyeye, A; Adelowo, F; Onawumi, O.O, Evaluation of the Chemical and Nutritional Values of Some Nigerian watermelon (Citrullus lanatus), Journal of Laboratory Science, Volume 1, number 1; Pp 37-41. 2012.

[3] Ayoola, P.B \& Adeyeye, A, Effect of Heating on the Chemical Composition and Physico - Chemical Properties of Arachis hypogeal (Groundnut) Seed Flour and Oil. Pak. J. Nutr. 9 (8); 745 - 756. 2011.

[4] Citrullus lanatus (Thunb) Mansf (Cucurbitaceae).www.globinmed.com/index,1/17/2011.

[5] Egan, H; Kirk, R.S. \& Sawyer, R., Pearson's Chemical Analysis of Foods. $8^{\text {th }}$ Edition. Churchill, Livingstone, N.Y; Pp 27 - 56. 1981.

[6] Ensminger, A.H \& Ensminger, M.K, Food for Health; In: $A$ Nutrition Encyclopedia Choris, California Pegus Press; Pp. 1061 - 1072. 1986.

[7] Gwana, A.M, Echeonwu, G.O.N, Auwal, M.S, Bagudu, B.Y, Mrs. Sa'adatu, H. S, Fatima, A.L, \& Abdullah, Study Area and Location; In: Survey on Hepatitis B Surface Antigen (Hbs $\mathrm{Ag}$ ) Amomgst the Community of Mohame Lawan College of Agriculture, Maiduguri, Borno State, North - Eastern Nigeria. Journal of Laboratory Science, 2, (1); Pp. 1 - 6. 2013. 
[8] Jules, Janick, Vine Crops; In: Tropical and Subtropical Fruits, Hurticultural Science. $2^{\text {nd }}$ Edition, W.H. Freeman and Company, U.S.A.; Pp. 537 - 538. 1972.

[9] Lees, R, Food Analysis, In: Analytical and Quality Control Methods for the Food Manufacturer and Buyer, $3^{\text {rd }}$ Edition, Leonard Hill Books, London; Pp. 5 - 96. 1975.

[10] "Melon (fruit)", Microsoft ${ }^{\circledR}$ Student 2008 [DVD]. Remond, WA: Microsoft Corporation, 2007. 2008.

[11] Sekoni, Tindal, and Adeniran, Medicinal Plant in Africa. Pp $34-40.1984$.

[12] Shul'man, G.E, Life Cycle of Fish Physiology and Biochemistry. Halted Press, John Wiley and Sons Inc: N.Y, $1^{\text {ST }}$ Edition; Pp. 101 - 106. 1974.

[13] Stray, F., The Natural Guide to Medicinal Herbs and Plants. Tiger Books International, London1st Edition; Pp.12 - 16. 1998.
[14] Stroud, K.A \& Booth, D.J., Statistical Package, In: Engineering Mathematics. WWW.Palgrave.Com/Stroud, Palgrave, GB, London, $5^{\text {th }}$ Edition; 1130 - 1139. 2001.

[15] "Watermelon", Microsoft ${ }^{\circledR}$ Student 2008 [DVD]. Remond, WA: Microsoft Corporation, 2007. 2008.

[16] WHFoods: Watermelon. www.whfoods.com/genpage,2011.

[17] Whitaker, T.W. \& Davis, G.N., Cucurbits; In: Botany, Cultivation, and Utilization (A Comprehensive Treatment of Cultivated Cucurbitaceae). Inter Science (Wiley), New York. Pp. 236 - 239. 1962.

[18] Worthington-Roberts, Bonne. "Human Nutrition". Microsoft ${ }^{\circledR}$ Student 2008 [DVD]. Redmond, WA: Microsoft Corporation, 2007. 2008. 